\title{
KAPABILITAS PEMERINTAH DESA MENGELOLA ASET DESA DALAM MENUMBUHKAN \\ KEWIRAUSAHAAN SOSIAL
}

(Studi Desa Gondowangi, Kecamatan Wagir, Kabupaten Malang, Jawa Timur)

Nyimas Nadya Izana1, Anik Susanti2, Dano Purbo3

1.Sosiologi, FISP, Universitas Brawijaya. nyimasnadyaizana@gmail.com, 082131050160

2. Sosiologi, FISIP, Universitas Brawijaya, aniksusantie@gmail.com, 085646771153

3.Sosiologi, FISIP, Universitas Brawijaya, danuᄀ_ub@yahoo.com, 089526996966

\begin{abstract}
Abstrak
Regulasi Pemerintah dalam mengelolah desa pada dasarnya bertujuan membangun kemandirian, bermacam metode pendekatan pendampingan telah diterapkan, tidak lain bertujuan mengelolah aset dan mengorganisir warga lokal. Hal tersebut telah tercantum dalam Undang -Undang No 6 Tahun 2014 dan No 2 tahun 2018. Desa Gondowangi sebelum kepemimpinan kepala desa saat ini, desa tersebut mengalami pasang surut yang membuat masyarakat setempat berpikir bahwa pemerintah desa sebagai pemerintahan yang bersifat struktural. Namun, berbeda ketika perubahan kepala desa yang baru. Kepala desa ini dapat menggerakkan masyarakat untuk mengembangkan potensi desa yang ada disekitarnya diantaranya adalah pamdes dan pengelolaan sampah. Dari keberhasilan yang dialami oleh Desa Gondowangi, membuat penulis untuk mendeskripsikan bagaimana strategi kepala Desa Gondowangi saat ini dalam mengelola asset desa dalam menumbuhkan kewirausahaan sosial?. Metode penelitian yang digunakan adalah kualitatif deskriptif. Hasil penelitian menunjukkan bahwa gerakan awal yang dilakukan kepala desa ialah dengan menyadarkan kepada warganya untuk memelihara desa sebagai warisan leluhur. bidang pelayanan publik terdapat pamdes dan pengelolaan sampah berfungsi meminimalisir resiko-resiko kekurangan air minum dan kerusakan aliran sungai. Saat ini Desa Gondowangi telah mampu secara mandiri menghidupkan pelayanan publik yang prima dan Bumdes yang berwawasan lokal.
\end{abstract}

Kata kunci: Desa, Pemerintah Desa, BUMDES 


\begin{abstract}
Government regulations in managing villages are basically aimed at building independence, various methods of assistance approaches have been implemented, none other than aiming at managing assets and organizing local residents. This has been stated in Law No. 6 of 2014 and No. 2 of 2018. Before Gondowangi village before the leadership of the current village head, the village experienced ups and downs which made the local community think of the village government as a structural government. However, it is different when the new village head changes. The village head can mobilize the community to develop the village potential that surrounds them including pamdes and waste management. From the success experienced by Desa Gondowangi, it made the writer to describe how the strategy of the village head of Gondowangi is currently in managing village assets in fostering social entrepreneurship. The research method used is descriptive qualitative. The results of the study indicate that the initial movement carried out by the village head was to make people aware of their village as an ancestral heritage. the field of public services has pamdes and waste management functions to minimize the risks of lack of drinking water and damage to river flow. At present Gondowangi Village has been able to independently turn on excellent public services and BUMDES with local insight.
\end{abstract}

Key words: Village, Village Government, BUMDES 


\section{Pendahuluan}

Pada tahun 2004 pemerintah menerbitkan undang-undang no 32 tahun 2004 tentang pemerintah daerah. Undang-undang ini merupakan revisi dari undang-undang no 22 tahun 1999. Dharmawan (2006) menyatakan bahwa undang-undang tentang pemerintah daerah tahun 2004 adalah salah satu landasan perubahan sistem tata- pengaturan atau tatapemerintahan (governance system) yang penting dalam sejarah pembangunan politik dan pengelolaan administrasi pemerintahan secara nasional. Karena negara Indonesia sudah terlalu lama menikmati sistem permerintaha yang sentralistik. Namun keberadaan undang-undang tersebut tidak memberikan wewenang kepada pemerintah desa untuk mengelola tata pemerintahannya sendiri. Sehingga mengakibatkan beberapa masalah diantaranya Wewenang yang melimpah di tingkat pemerintah kabupaten, sebagai akibat diberlakukannya OTDA, justru telah menyebabkan munculnya gejala baru berupa "resentralisasi" kekuatan dan akumulasi kekuasaan yang berlebihan di tingkat otoritas-kabupaten/kota. Akibatnya, kemandirian desa (sebagai wilayah-administrasi di bawah hierarkhi kabupaten) kembali mengalami “dekapitalisasi kekuasaan”, dimana desa "gagal” mendapatkan dukungan modal-politikal dan modal-kultural yang diperlukan bagi tumbuhnya sistem pengaturan desa yang mandiri dan berwibawa (Dharmawan, 2006).
Permasalahan ini membuat pemerintah untuk membuat undang-undang no 16 tahun 2014 tentang desa. Melalui undang-undang tersebut, desa diposisikan sebagai "pemerintahan masyarakat" yang memiliki kewenangan luas menyelenggarakan urusan pemerintahan dan kemasyarakatan baik berlandaskan sistem desa otonom yang disebut "desa" ataupun sisten organisasi adat yang disebut "desa adat" (Shohibuddin, 2012). Keberadaan undangundang desa menempatkan desa sebagai ujung tombak pembangunan dan peningkatan kesejahteraan masyarakat. Sehingga setiap tahunnya pemerintah pusat menganggarakan dana desa yang cukup besar yaitu pada tahun 2015 dana desa dianggarkan sebesar Rp20,7 triliun, dengan rata-rata setiap desa mendapatkan alokasi sebesar Rp280 juta. Pada tahun 2016, Dana Desa meningkat menjadi Rp46,98 triliun dengan rata-rata setiap desa sebesar Rp628 juta dan di tahun 2017 kembali meningkat menjadi Rp 60 Triliun dengan rata-rata setiap desa sebesar Rp800 juta. Berdasarkan buku saku dana desa menyatakan bahwa tiga tahun pelaksanaannya, Dana Desa terbukti telah menghasilkan sarana/prasarana yang bermanfaat bagi masyarakat, antara lain berupa terbangunnya lebih dari 95,2 ribu kilometer jalan desa; 914 ribu meter jembatan; 22.616 unit sambungan air bersih; 2.201 unit tambatan perahu; 14.957 unit PAUD; 4.004 unit Polindes; 19.485 unit sumur; 3.106 pasar desa; 103.405 
unit drainase dan irigasi; 10.964 unit Posyandu; dan 1.338 unit embung dalam periode 2015-2016 Supaya desa dapat menggunakan dana desa secara efektif maka terdapat aturan dari pemerintah, salah satunya adalah Bupati Kabupaten Malang mengeluarkan aturan mengenai pedoman pelaksanaan alokasi dana desa nomer 35 tahun 2017 yang menyatakan bahwa salah satu sumber pendapatan Desa adalah ADD. Sehubungan dengan hal tersebut, maka dalam pengelolaan ADD diperlukan suatu standar pengaturan yang dimulai dari aspek perencanaan, penganggaran, pelaksanaan, penatausahaan keuangan Desa dan pertanggungjawaban keuangan Desa. Berdasarkan data Direktorat Jendaral Perimbagan Keuangan (DJPK) menyatakan bahwa Kabupaten Malang menerima rincian dana desa tahun anggaran 2017 sebesar Rp 312.979.737 dengan jumlah desa 378 .

Kunci sukses untuk mensejahterakan masyarakat dalam membangun desa adalah kuatnya sentuhan inisiasi, inovasi, kreasi dan kerjasama antara aparat desa dengan masyarakat dalam mewujudkan apa yang menjadi cita-cita bersama. Pembangunan desa tidak mungkin bisa dilakukan aparat desa sendiri, tapi butuh dukungan, prakarsa, dan peran aktif dari masyarakat. Hal ini dialami oleh salah satu desa yang ada di Kabupaten Malang yaitu Desa Gondowangi, Kecamatan Wagir. Pemerintahan Desa Gondowangi sempat mengalami pasang surut karena pemerintahan yang kurang transparan dalam pengelolaan dana dan dianggap menyimpang dari prinsip-prinsip yang dijabarkan dalam perdes. Desa ini merupakan desa yang mempunyai cukup banyak aset atau potensi, hal tersebut dibuktikan adanya kegiatan masyarakat yang berkaitan dengan pertanian dan penggunaan sumberdaya air selama ini masih tetap berlangsung. Program-program yang dibuat merupakan bentuk kewirausahaan sosial, karena hal ini tidak menguntungkan pribadi namun menguntungkan masyarakat luas khususnya Desa Gondowangi. Dari pemaparan tersebut membuat penulis ingin mendeskripsikan bagaimana kapabilitas pemerintah desa mengelola aset desa dalam menumbuhkan kewirausahaan sosial?

\section{METODE}

Penelitian ini dilaksanakan di Desa Gondowangi, Kecamatan Wagir, Kabupaten Malang. Desa ini memiliki berbagai persetasi diantaranya adalah Pamdes "Tirto Ageng” juara 3 HIPPAM (Himpunan Penduduk Pemakai Air Minum) se-Jawa Timur, pengelolaan sampah dan lumbung pangan. Ketiga hal tersebut merupahan bentuk BUMDES yang mereka kelola.

Penelitian ini bertujuan untuk mendeskripsikan kapabilitas pemerintah desa menglola aset desa dalam menumbuhkan kewirausahaan sosial. Untuk mencapai tujuan tersebut peneliti menggunakan metode kualitatif deskriptif. Dengan melakukan pengamatan (obeservasi) dan wawancara mendalam (in depth interview). Wawancara mendalam dilakukan kepada informan-iforman yang menjawab rumusan malsah pada penelitian ini. Informan 
diambil dari pemerintah desa, karang taruna dan masyarakat Desa Gondowangi. Dalam teknik analisis data menggunakan kondensasi data, menampilkan data dan kesimpulan (Miles, Huberman dan Saldana, 2014). Kondensasi data adalah proses seleksi, memfokuskan, mentransormasi data dari catatan lapangan. Setelah melakukan kondensasi data selanjutnya adalah penyajian data. Penyajian data yaitu kumpulan informasi dari catatan lapangan yang terorganisir dideskripsikan yang selanjutnya data-data tersebut dapat menarik kesimpulan.

\section{HASIL DAN PEMBAHASAN}

Tantangan dalam mempersuasi Warga Desa Gondowangi

Jika dirunut dari awal mula bagaimana kepala Desa Gondowangi dapat membawa desa kedalam program-program yang menguntungkan masyarakat adalah dengan mengubah cara berpikir masyarakat setempat. Hal ini dilakukan oleh kepala desa saat ini, dengan cara mengkonstruksi pengetahuan kepada masyarakat sekitar bahwa wilayah (Desa Gondowangi) yang mereka tempati saat ini adalah warisan leluhur. Jika tidak dijaga bagaimana keadaan di masa mendatang. Sehingga dibutuhkan tindakan untuk menjaga dan mengembangkan apa yang telah diberikan oleh leluhur, jangan sampai hanya pergi ke makam dan membaca tahlil. Menjaga disini yaitu dengan cara menjaga hubungan sosial antar warga Desa Gondowangi, saling bergotong-royong dan menjaga ketentraman.

Apa yang dilakukan oleh kepala desa tidaklah mudah. Hal ini disebabkan karena persepsi masyarakat mengenai pemerintah desa itu sebagai pemerintahan yang bersifat struktural. Sebelum kepemimpinan kepala desa saat ini, terjadi beberapa masalah yang membuat masyarakat Desa Gondowangi tidak suka dengan pemerintah desa. Pertama, pada saat pemerintahan kepala desa ke-3 ternyata warga desa melakukan unjuk rasa diakibatkan adanya pungutan liar dengan alasan untuk pembangunan desa karena tidak ada diskusi terlebih dahulu antara pemeirntah desa dengan perwakilan masyarakat, yang pada akhirnya timbulnya rasa tidak percaya kepada pemerintah desa. Kedua, pada masa jabatan 2008 - 2013 kepala Desa Gondowangi adalah perempuan. Dan gaya kepemimpinan yang dilakukan tidak bisa memposisikan masyarakat sebagai pelaku pembangunan, pola yang diterapkan mirip seperti kepala desa sebelumnya. Contohnya ketika kepala desa saat ini membuat proposal untuk kegiatan karang taruna mengenai pengelolaan sampah dengan mengajak warga yang mempunyai perilaku yang tidak sesuai dengan norma yang ada di masyarakat, sehingga program tersebut di tolak oleh kepala desa.

Pada bulan Desember 2013 akhirnya terpilihlah Bapak Danis Setia Budi Nugroho sebagai kepala Desa Gondowangi sampai saat ini. Cara untuk mempersuasi masyarakat setempat yaitu dengan cara bertemu langsung warga desa dengan berkunjung ke rumah. Hal ini dilakukan setiap hari dari pukul 18.00 sampai dengan 03.00. tujuannya kepala desa berkunjung ke rumah warga adalah untuk dapat menerima kembali keberadaan pemerintah desa di tengah- 
tengah masyarakat Desa Gondowangi supaya dapat membangun desa secara bersama-sama

Kapabilitas Pemerintah Desa Mengelola Aset Desa dalam Menumbuhkan Kewirausahaan Sosial Meiwanda (2016) menyatakan kapabilitas organisasi merupakan kombinasi dari keahlian/kompetensi sumber daya manusia (SDM) dan kapasitas organisasi untuk menerapkan keahlian yang dimiliki SDM-nya, sehingga kapabilitas organisasi lebih dari sekedar sumber daya manusia tapi juga menyangkut "sistem" dan "proses". Sehingga dapat dikatakan bahwa kapabilitas adalah kemampuan menggunakan sumber daya yang ada di dalam diri maupun di dalam organisasi untuk menjalankan aktivitas tertentu. Jika dikaitkan dengan keadaan di Desa Gondowangi, bahwa pemerintah desa mampu mempersuasi masyarakatnya untuk memajukan Desa Gondowang menjadi desa mandiri.

Proses dan sistem yang dibentuk oleh pemerintah Desa Gondowangi adalah meneruskan program pamdesa yang sebelumnya mengalami pasang surut. Pada awal masa jabatannya pamdes dalam keadaan terpuruk yang ditandai dengan hampir warga Desa Gondowangi tidak mempunyai air akibat dari perawatan yang minim. Selain itu adanya tunggakan pembayaran penggunaan air. Hal ini disebabkan tidak adanya aturan yang jelas menangani hal tersebut dan adanya mosi tidak percaya kepada kepala desas sebelumnya. Untuk memperbaiki kelembagaan ini, kepala desa yang baru berusaha untuk menyelesaikannya permasalahan yang dihadapi. Terdapat beberapa cara yang digunakan oleh kepala desa saat ini, diantaranya :

1. Melakukan pemetaan potensi desa

2. Menambahkan sumber air

3. Pembangunan tendon besar dan pemipaan tiga kilometer secara swadaya

4. Penataan ulang kelembagaan pamdes

5. Membentuk struktur organisasi dengan Surat Keputusa Kepengurusan yang berkekuatan hukum yang berdasarkan struktur organisasi yang telah disetujui oleh forum musyawarah desa dengan nomer no.180/091/421.608.007/2014 yang dibuat pada tanggal 25 Ferbuari 2014 dan memiliki masa bakti tiga tahun.

Kedua, mengenai pengelolaan sampah. Program ini merupakan inisiasi Pak Danis sebelum diangkat menjadi kepala desa. Program ini aktif pada tahun 2005 tanpa bantuan dari pemerintah desa, namun bantuan dari Pemerintah Kabupaten Malang. Hal ini disebabkan karena Pak Danis mengajukan proposal yang beranggotakan para warga desa yang berprilaku tidak sesuai dengan norma masyarakat Desa Gondowangi. Awal mula keterlibatan program ini sebanyak 50kk dengan biaya Rp. 3000,-/KK. Saat ini yang mengikuti program tersebut sebanyak $750 \mathrm{kk}$ dengan biaya Rp 8000,-/kk. Keadaan ini lebih memanusiawikan para pengurus yang dahulu hanya mendapatkan gaji sebesar Rp.80.000,/bulan dan sekarang mendapatkan gaji sebesar Rp. 2.000.000,-/bulan.

Ketiga, mengenai lumbung pangan. Awal mula dibentuknya program ini adalah rendahnya 
hasil jual petani ketika panen berlangsung, berdasarkan pada hasil penelitian menunjukkan bahwa petani tidak mempunyai alasan untuk menolak harga yang ditentukan tengkulak yaitu Rp. 6.500 sampai Rp. 7.000 perkilogram (dalam bentuk gabah). Sedangkan jika ditinjau ulang dengan harga pasaran yaitu Rp. 7.500- 8000 rupiah. Kondisi tersebut menyebabkan kondisi hasil panen petani Gondowangi tidak mampu mempunyai penyisihan (tabungan) untuk disimpannya, sehingga mereka banyak merasa rugi dengan adanya standar harga yang ditentukan oleh tengkulak. Dengan begitu, Kepala desa dan stafnya mengajak kelompok petani SUMBER MAKMUR I \& II sama-sama merumuskan untuk mencari solusi yang mereka inginkan bersama.

Kusumasari (2014) menghubungkan kapabilitas pemerintah dan faktor penting didalam pelaksanaan, yaitu kelembagaan, sumber daya manusia, implementasi kebijakan, keuangan dan kepemimpinan. Berikut yang ditemukan oleh peneliti di lapangan. Kelembagaan (institution) disebut juga dengan aturan main yang isinya berbeda antara level makro dan level mikro. Pada level makro, kelembagaan berisi seperangkat aturan politik, sosial dan legal yang memapankan kegiatan produksi, pertukaran dan distribusi. Sedangkan pada level mikro, kelembagaan berhubungan dengan masalah tata kelola aturan main agar pertukaran antarunit ekonomi bisa berlangsung, baik lewat kerjasama maupun kompetisi (Yustika, 2008:xi). Dilapangan ditemukan beberapa kelembagaan yang ada di setiap program diantaranya adala (1) program pamdes, aturan pertama mengenai pembayaran. Setiap konsumen pamdes diwajibkan membayar Rp.500,-/kubik untuk warga Desa Gondowangi sedangkan untuk warga Desa Parang Agro Rp. 1.000,-/kubik. Ada kekurangan dalam sistem pembayaran yaitu tidak ada perbedaan antara rumah tangga dan usaha. Bagi konsumen keluarga miskin tidak dipungut biaya. Kedua, konsumen harus membayar tagihan kepada pengurus Pamdes “Tirta Ageng” setiap tanggal 10 sampai 20 setiap bulannya, (2) pengelolaan sampah, pertama mengenai aturan pembayaran dalam mengikuti program ini adalah membayar iuran Rp. 8000,-/kk/bulan. Kedua mengenai pengambilan sampah yang dilakukan setiap dua minggu sekali di setiap rumah yang telah membayar bulannya. Setelah itu, petugas menghimpun dan memilah sampah. Ketiga mengenai pembagian dana dari iuran yang sudah di bayar oleh warga desa yaitu $25 \%$ untuk perawatan alat-alat, seperti pemeliharaan gerobak sampah. $75 \%$ digunakan untuk gaji karyawan yang terdiri dari 3 orang. (3) mengenai lumbung pangan terdapat beberapa aturan dari 32 Hektar harus menyetorkan hasil panennya dalam bentuk gabah, kepada Pemerintah Desa Gondowang; Harga kilogram ditentukan oleh pemerintah desa, dengan syarat menyesuaikan dengan harga Bulog dan tengkulak; petani yang ingin menjual kepada tengkulak, dipersilahkan asalkan harga yang ditentukan harus diatas ketentuan desa; petani tidak menerapkan hasil keputusan tersebut akan dikenakan sanksi sosial 
berupa pengucilan atau digunjing oleh sesama petani;

Sember daya manusia di Desa Gondowangi berperan aktif di dalam menjalankan semua program yang dilakukan oleh pemerintah desa sehingga membuat program-program yang dibuat bermanfaat bagi warga Desa Gondowangi. Dana-dana yang dberikan kepada program-program tersebut adalah ADD Desa Gondowangi yang mana implementasi kebijakan-kebijakan yang dibuat dapat terlihat dari hasil program yang sudah dilakukan. Model kepemimpinan kepala Desa Gondowangi memiliki kemampuan untuk menggayomi masyarakatnya demi menjadi desa yang mandiri

Program-program yang dilakukan oleh pemerintah desa merupakan program tentang kewirausahaan sosial. Berdasarkan Sakai, et al (2018) mengemukakan bahwa kewirausahaan sosial adalah semua bentuk usaha sosial dengan tujuan menyelesaikan masalah sosial. Menyelesaikan masalah sosial dengan cara-cara inovatif seperti memadukan kearifan lokal dan inovasi sosial (Inovasi sosial yaitu bagaimana masalah sosial bisa diatasi dengan cara-cara kreatif dan inovatif antara pelaku bisnis dan praktisi social, baik organisasi atau perorangan.). Jika dikiatkan dengan program-program yang dilakukan oleh pemerintah desa dengan kepemimpinan Pak Danis merupakan program kewirausahaan sosial. Hal ini dikarenakan semua program yang dilakukan untuk menguntungkan masyarakat Desa Gondowangi dan dapat menyelesaikan masalah sosial dengan menggunakan pengetahun-pengetahun local mereka. Karena kewirausahaan sosial tidak terlepas dari aspek lokalitas dari praktik penerapannya. Pemerintah Desa Gondowangi memanfaatkan warganya dan perangkat desa untuk mengelola program-program tersebut dari warga yang mempunyai perilaku tidak sesuai dengan norma yang ada di masyarakat sampai warga yang mempunyai pengalaman dalam bidangnya masing-masing. Hal ini sesuai dengan yang dikatakan oleh Wibowo dan soni, 2015 dalam Sakai, et al ,2018 bahwa Output kewirausahaan sosial adalah menyediakan jasa dan produk yang tidak mampu disediakan oleh pasar atau sektor publik, membangun keterampilan, menciptakan lapangan pekerjaan, membangun jalan untuk menghubungkan orangorang yang terpisah secara sosial.

\section{Kesimpulan}

Dari penjelaskan di atas dapat disimpulkan bahwa dengan pemerintah Desa Gondowangi mempunyai pengetahun untuk memajukan desanya sehingga pemerintah desa mampu mempersuasi kepada masyarakat dan mengubah persepsi masyarakat desa untuk berperan aktif didalam program-program desa untuk menjadikan desa mandiri 


\section{Daftar Pustaka}

,http://www.djpk.depkeu.go.id/wp-

content/uploads/2016/11/RINCIAN-ALOKASI-

DANA-DESA-TA-2017-UPLOAD.pdf diakses

pada tanggal 27 Februari 2019

Kusumasari, Bevaloa. 2014. Manajemen

Bencana dan Kapabilias Pemerintah Lokal. Gava

Media: Yogyakarta

Miles, Mathew B, Hubermen, A Michael,

Shaldaria, Johnny. 2014. Qualitative Data

Analysis A Methods Soucebook

Sakai, Minako et al. 2018. Kewirausahaan sosial

tinjauan konsep dan terapan dalam organisasi

sosial. Tiara Wacana: Yogyakarta

Yustika, Ahmad Erani. 2013. Ekonomi

Kelembagaan. Erlangga: Jakarta

\section{Biodata Setiap Penulis}

Nyimas Nadya Izana, Pengajar di Universitas Brawijaya. Menyelesaikan S1 di Departemen Sains Komunikasi dan Pengembangan Masyarakat dan S2 di Sosiologi Pedesaan, Fakultas Ekologi Manusia, Institut Pertanian Bogor. Fokus penelitian saat ini tentang isu-isu yang berkaitan dengan agrarian, pertanian di pedesaan, kelembagaan desa, industrialisasi. 